\title{
Euripides' Ion and the charges of slavery laid against Alcibiades
}

Michael VICKERS

Jesus College, Oxford

It can be no secret that for the past few years I have been putting forward the view that Attic tragedy and comedy were originally intended to serve as a commentary—often a close commentary-on current events. The mercurial and fickle personality of Alcibiades figures large in the picture that emerges. And not simply Alcibiades, but his extended family, including his foster-father Pericles, and the woman who played the role of a mother in the Periclean household, Aspasia. On this view, dramatic productions played the same role as political cartoons today: tragedy was akin to the more sombre and serious kind, comedy the more flippant. Greek dramas were intended to reflect specific historical situations before some of them became great literature written for all time. But just as the political cartoon is evanescent, with very few receiving canonical status, so too, of the thousands of tragedies and comedies to have been written, fewer than four dozen have survived, and often for the most bizarre reasons. It was, for example, Antigone's 'Christian love' that allowed enthusiastic teaching of the play in Byzantine schools and contributed to the preservation of the Sophoclean corpus. Even more bizarre is the almost total rejection today of seeing drama in terms of contemporary history. Ever since Wilamowitz declared that "no Sophoclean tragedy has any immediate connection with a contemporary event", few scholars have dared to stray into forbidden territory. Students of Euripides have only gingerly followed Günther Zuntz in admitting that some at least of Euripides' plays might be political, and most would agree with E.R. Dodds repeated declaration that "what is outside the play does not exist".

Classical Papers, vol. xi , 2012 


\section{- Euripides' Ion and the charges of slavery laid against Alcibiades}

In this paper I consider an aspect of a play written at Athens in the closing years of the fifth century $\mathrm{BC}$. A burning issue facing writers for the stage in these years was "What would you do about Alcibiades?" The question as we have it was voiced by Aristophanes in Frogs in 405 BC (lines 1422-3), but it exercised playwrights long before then. The reason was not far to seek, for Alcibiades was the most controversial individual of his age; having been "the leader of the dissolute younger generation" (Ehrenberg 104-5); having been elected one of the three generals for an expedition against Sicily (a campaign he had done much to promote); having been suspected of involvement in various acts of impiety before the departure of the fleet; having been recalled from Sicily to stand trial; having jumped ship and gone into exile at Sparta; having advised the Spartans on the most effective ways to defeat Athens; having then fled to take refuge with the Persian satrap Tissaphernes before taking command of the Athenian forces on Samos; having returned to Athens in glory, and having gone into exile once again. He captured the imagination of friend and foe alike, electrifying Athenian drama, but one must look long and hard to find discussion of the evidence for this in modern scholarship relating to Greek tragedy, which largely resists any notion that plays might deal with day to day politics, and in particular with the career of individuals such as Alcibiades.

Aristotle gives us an important clue when he differentiates between history and drama: history was personal and dealt in particulars. The example he chose is "what Alcibiades actually did, or what was done tod that him" (Poetics 1451b.11), whereas drama describes the kind of things that "a person of a certain character would inevitably say or do" given their known proclivities and predilections (Poetics 1451b.9). It is not such a bold step to infer that drama might often be concerned with what Alcibiades had recently done, or might be expected to do, given what was known about him; elements which, however, naturally fall "outside the play". There is also Libanius' rhetorical question: "What play did not include Alcibiades among the cast of characters?" (Libanius Fragment 50.2.21); for all that Libanius appears to be referring to comedy, his observation might easily 


\section{Michael VICKERS}

apply to tragedy as well. In my recent Sophocles and Alcibiades, I suggested five of the seven extant Sophoclean tragedies deal with Alcibiadean themes (Vickers Sophocles).

Greek playwrights might, moreover, be venal, might be corrupt. This is a point that has largely escaped modern critics, but it did not escape Plato, who excluded "poetry" from his ideal republic probably for this very reason (tragic poets were his chief target: Republic 595b4, 597e6, 598e8, 602 b9, 605c11, 607a3; cf. 595c1). It has been wisely said that "The poets are rhetoricians who are, as it were, selling their products to as large a market as possible, in the hope of gaining reputation and influence" (Griswold) - but reputation and influence for their patrons, and presumably financial gain for themselves. Euripides, for example, had been in Alcibiades' pocket ever since he wrote a praise poem in honour of Alcibiades' Olympic victory of 416 BC. Euripides obsequiously (and inaccurately) attributed first, second and third places to his patron; in fact, Alcibiades' teams were placed first, second and fourth. Euripides' position was akin to that of Simonides, Pindar or Bacchylides with respect to their patrons. The poets traded their skills for riches. We only have one statistic, but it is a telling one: Pindar was paid 10,000 drachmas (= 43 kilos of silver) for verses in honour of Athens in the 470s BC (Isocrates 15.166; Pindar Fragment 75 Snell).

It will not be surprising therefore to see Euripides after 416 putting the most generous interpretation on Alcibiades' actions, defending his reputation, and making a strong case for his forgiveness and return. Whether in his Helen of 411, his Ion of 409, or his Bacchae of 407/6 BC, there is a consistently pro-Alcibiadean line being pushed. I have discussed this in greater detail elsewhere; today I simply wish to explore a couple of ways in which Euripides the spin-doctor went about his business in the context of Ion. The plot of Ion is complex, but the outlines may be summarised as follows: "Apollo ... has ravished Creusa, an Athenian princess, and by her engendered a son whom he intends to make king of Athens, father of the Ionian race, and patron of the Ionian colonies. The 


\section{- Euripides' Ion and the charges of slavery laid against Alcibiades}

design of the god, known to the audience from the beginning, is not made manifest to the characters of the play until the end, when they depart praising him for his benevolence" (Burnett 89).

Sophocles usually stresses Alcibiades' negative qualities, but Euripides does the opposite. There was a lot that was negative about Alcibiades and Euripides could scarcely conceal it. In fact he does not do so in Ion, but creates a series of small errors, slips and misunderstandings that recall Alcibiades' major sins, but which are serially forgiven or clarified in such a way that it might seem that the major transgressions should be set aside as well. A minor example is to be found at the point where Creusa declares that Ion's behaviour in drawing attention to her tears is oủk ámaıઠॄútos (line 247: "not impolite [literally 'not uneducated']"). Alcibiades was notoriously ámá́ठฮuto (e.g. Antisthenes Fragment 30 in Athenaeus $12.534 c$ ). In having us see a small breach of manners excused in this way, Alcibiades' spin-doctor is subliminally encouraging his audience to forget that Alcibiades was severely maleducato.

A major example of the phenomenon concerns slavery. To be a slave, or to have servile origins, was a matter for acute shame in ancient Greece. There are indications that Alcibiades' maternal ancestor, the first Coesyra who came from Eretria, may have been a slave (Scholia to Aristophanes Clouds line 64; Peace line 451). Alcibiades is also said to

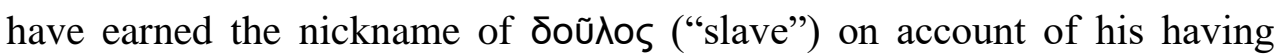
deserted to the Spartans in 415 BC (Scholion to Peace line 451). And whether or not these traditions are valid, it was certainly the case that on entering the service of Tissaphernes in 412 BC the exiled Alcibiades technically became the doulos of the Persian satrap. Euripides could not overlook stories of Alcibiades' servile origins or his recent slave status, but he neutralizes them in a highly skilful manner. Ion's service is not to a

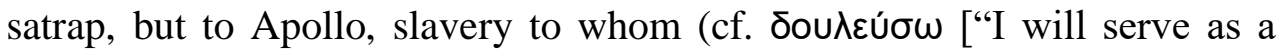
slave"]: line 182; тоũ $\theta \varepsilon$ ка the god"] line 132; line 309; line 327) is no disgrace. Hermes explicitly

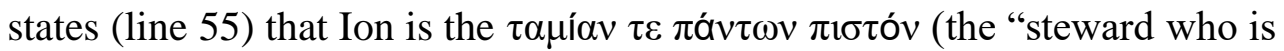




\section{Michael VICKERS}

trusted above all") at Delphi; phraseology highly reminiscent of (and scarcely unconnected with) the reports we receive in Plutarch of

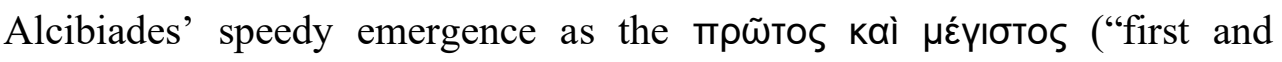

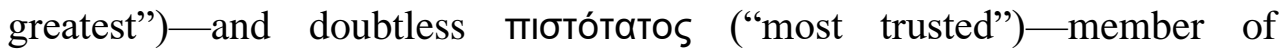
Tissaphernes' court in 412 BC (Plut. Alc. 24.4). When Ion understands from Xuthus that his birth may have been the result of an encounter with a free-born woman (lines 551-6) he is relieved to have escaped the charge of

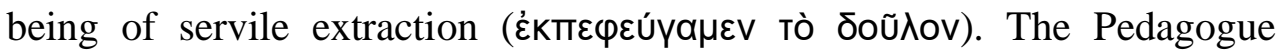
takes up the burden of Euripides' spin-doctoring at lines $836 \mathrm{ff}$. when it seems to him and Creusa that Xuthus may indeed have had his purported fling with a woman who may after all have been enslaved ( $\dot{\varepsilon}$ Koúdn yuvaı́ós: lines 837-8), and then dwells on what a shameful thing it is to bear the name of slave (lines 854-5). In passing, Euripides makes a glancing allusion to another scandalous fact concerning Alcibiades that could not be glossed over, namely his having bought a captive slave woman after the sack of Melos in $416 \mathrm{BC}$, having taken her as a mistress, and having had a child by her. This was considered this to be "a lawless outrage" of a kind more often "seen on the tragic stage" (Pseudo-Andocides 4.23). A memory of this event probably lies behind the Pedagogue's complaint that it is an awful thing to take the child "of some slave woman" into one's house (lines 836-8). Ion is concerned that the recognition-tokens with which he is entrusted by the Pythian priestess may yet reveal that his mother was a slave (line 1382). Ion's freeborn status is eventually made clear, however, and without specifically saying so, Euripides in effect implies that so far as Alcibiades was concerned, it was time to "draw a line" under the slavery issue and "move on".

This is but part of the case I would make for Ion being an attempt by Euripides to render Alcibiades' public image more acceptable, an urgent political issue in $409 \mathrm{BC}$; and his propaganda will have contributed to Alcibiades' triumphal return to Athens in 407 BC. Euripides cleverly glosses over his patron's less attractive features and substitutes piety for impiety, potential statesmanship for less than patriotic achievement, and 
- Euripides' Ion and the charges of slavery laid against Alcibiades

above all forgiveness and reconciliation for discord and disharmony: and free birth for slavery.

'When he was a young boy he lured husbands away from their wives, but when he was a young man he lured wives away from their husbands' (Bion ap. Diog. 4.49). 